DOI: https://doi.org/10.34069/AI/2021.43.07.1

How to Cite:

Tatarinov, A., \& Bezrukavaya, M. (2021). The Human Concept in Russian Neomodernist Prose of the 21st Century. Amazonia Investiga, 10(43), 9-19. https://doi.org/10.34069/AI/2021.43.07.1

\title{
The human concept in Russian Neomodernist prose of the 21st Century
}

\section{Концепция человека в русской неомодернистской прозе XXI века}

Received: June 16, 2021

\begin{abstract}
Research subject is grounding efficiency and topicality of Russian literature (and its studies) as a cultural project, that could be apologia of a traditional individual. Methodological basis is anthropocentric literature of Erich Auerbach, Dmitry Likhachev, Sergey Averintsev, Harold Bloom, in which literary text analysis, assessment of genre structures lead to the conclusions on the individual's state under the established cultural tradition. Analysis of contemporary Russian novels outlines authors' worlds. Reading them evokes various images: of a passionate individual, often with certain intent, but always affected by the interaction with crises and voids (Yury Buida), an individual characterized by various anti-totalitarian acts, by aspiration to exercise the freedom of thought in everyday life (Ludmila Ulitskaya), an egocentric individual, believing that the most significant victories come in the representation of the own self (Edward Limonov), an individual prone to interaction with totalitarian principles, synthesizing non-canonic metaphysical forms and attributes of strong state under ambivalent relations of utopia and anti-utopia (Vladimir Sorokin), an individual actively exploring modern world and general existence in motions, related by the author to Oriental cognition principles and spiritual practices (Victor Pelevin). Our focused literary analysis aims at combining all text moves in plot and language that represent evolvement of a person as one of the central problems of any novel.
\end{abstract}

Abstract
Accepted: August 1, 2021

Written by:

Alexey Tatarinov ${ }^{1}$ https://orcid.org/0000-0001-8708-3918

Marina Bezrukavaya ${ }^{2}$ https://orcid.org/0000-0001-8334-5634

\section{Аннтация}

Предмет исследования - обоснование эффективности и актуальности художественной словесности (и ее изучения) как культурного проекта, который можно назвать апологией традиционного человека. Методологическая основа исследования антропоцентрическое литературоведение (Эрих Ауэрбах, Дмитрий Лихачев, Сергей Аверинцев, Харольд Блум), в котором анализ художественного текста, оценка жанровых структур приводят к выводам о состоянии личности в контексте состоявшейся культурной традиции. Результат анализа новейших русских романов - идентификация состоявшихся авторских миров. В процессе чтения возникают образы человека страстного, часто имеющего замысел, но всегда оказывающегося в своеобразном плену у стиля взаимодействия с кризисами и пустотами (Ю. Буйда), человека разных антитоталитарных жестов, всегда стремящегося реализовать свою свободу в мысли и повседневном существовании (Л. Улицкая), человека эгоцентрического, уверенного, что самые важные победы приходят в постоянной репрезентации собственного «Я» (Э. Лимонов), человека, склонного к взаимодействию с тоталитарными началами, синтезирующего неканонические формы метафизики и знаки сильного государства в контексте амбивалентных отношений утопии и дистопии (В. Сорокин), человека, активно познающего современный мир и общее состояние бытия в движениях, которые автор склонен возводить к восточным принципам

\footnotetext{
${ }^{1}$ Doctor of Philological Sciences, Professor, Kuban State University, Krasnodar, Russia.

${ }^{2}$ Doctor of Philological Sciences, Associate Professor, Kuban State University, Krasnodar, Russia.
} 
Keywords: artistic metaphysics, historiosophy, neo-modernism, personality concept, Russian prose. познания и духовной практики (В. Пелевин). Наш целенаправленный литературове дческий анализ направлен на объединение всех сюжетных и языковых ходов текста, представляющих эволюцию личности как одну из центральных проблем любого романа.

Ключевые слова: русская проза, неомодернизм, концепция личности, художественная метафизика, историософия.

Similar methodological approach is suggested, for instance, by Averintsev (1977) and Bloom (1994) in their books. They do not merely regenerate personality images in various cultures, but consider the image of man to be the most significant symbol of the author's world and the historical period behind him. Philological anthropocentrism implies intellectual space focused on literary reconstructed life pattern and worldview dominants. The issue of man (as the pinnacle of cultural tradition and personified way of testing it) is one of the crucial ones.

Following anthropocentric logic, relevant in contemporary philology, we aim at revealing significant images of a person, and defining literary expressed idea of a contemporary human. Artistic realization of a person is to be investigated under the hypothesis about the uniqueness of the last decade literary process. Many phenomena in contemporary literature tend to move from outdated postmodernism to neomodernism - subjective, creative method aimed at aesthetic reconstruction of prosaic and primarily novel reality. Ways of contemporary prose by Tatarinov (2015) depicts detailed hypothesis of contemporary era bearing neomodernist features.

First decades of the new millennium witness ideological and artistic dualism of Russian literature with oppositions of realistic postmodernist, patriotic - liberal, mass individual and aesthetic. It is poetics of boundary, ambivalent narratives, not modernism or postmodernism, that prevails and shapes axiological move in contemporary prose.

Hence, the term "neomodernism" acquires upmost importance. It denotes controversial, debated reality - a considerable volume of contemporary literature is filled with author's subjectivity, ideological activity, and conceptual idealism. Neomodernism can also be viewed as 


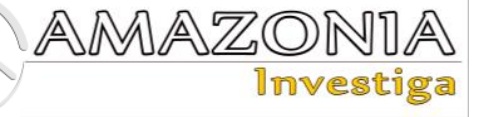

a promising way to revitalize literary process. Whereas postmodernism nearly always marks the crisis of classical prose and poetry, neomodernism requires recognition of the new perspectives. The concepts of man by the influential writers (Buida, Limonov, Sorokin, Pelevin) under the concept of anthropological processes of the early 21 st century generally oppose playful, entropic, demythologizing literary trends of the late 20th century.

\section{Literature Review}

As Zatonsky (2000) fairly stated, postmodernism tends to anti-utopia, while utopia is the field of modern. Modernism is religious in itself, postmodernism is indifferent to metaphysics; modern implies personalistic consciousness, while postmodern - mass one. Western modernism was more prone to experiment with the form. It correlates with linguistic scope of philology, the word exists in the frames of worldview providing answers for many ontological questions. It seems appropriate to point at atheistic nature of western postmodernism, its freedom from philosophy of history aspects. The situation is different in Russia: dual, radically disputable nature of metaphysical, historical and philosophical issues necessitates addressing the issue of neomodernism in Russian literature of the early 21 st century.

Zhitenev's monograph Poetry of neo-modernism (2012) on Russian poetry of the last decades turned to be the philological text invoking the neomodernism issue in contemporary literature. The author states that Russian poetry of the 20th21 st centuries refers to neomodernism, not postmodernism (a standard opinion within the frames of Russian literary activity). The concept is based on the extensive poetic material of numerous authors. Intensive discussions sparked on philological and literary-critical platforms, with main focus on theoretical aspects of the debated approach, unconventional methodological arrangement of artistic phenomena, previously used to be generalized as "postmodernism" (e.g. Lipovetsky, 2013). Postmodernism is often perceived in playful context, associated with lack of seriousness and cultural impact. Modernism retains its serious status, with the author initiating artistic programme, not just offering plots and images. This programme can coincide with life programme. Hence, permissible change of the view (from "modernism" to "postmodernism") does enhance the status of the phenomenon under investigation.
It is noteworthy to reveal key features of modernism, affecting the character of time issue. Despite its modernity, postmodernism as overwhelming cultural phenomenon deals with established traditions, transforming or deconstructing them. Epistemological value can not be high therefore. The case is different with modernism. It aspires to deal mainly with future time contexts, not past. Postmodernism is transformation of long-known, exposed to mass, too conventional perception, while modernism is artistic activity on recreating new values. It is another argument to back Zhitenev's formula (2012)

Postmodernism is the death of the subject to strengthen roles of theoretical constructions, and neomodernism is resurrection of the subject. This statement appears to be significant. Neomodernism returns to the moral development and relations of a man and an object (Chrząszcz, 2017). Contemporary literature (including both prose and poetry) is often assessed as a serial product, and this concerns not only mass texts (Doraiswamy, 2007). "Neomodernism" implies not an impersonal flow of "playful" information, that literary analyst deals with, but already established individual worlds shaping the future, and not playing with the familiar past.

Neomodernism, being focused on the subject's fate (Pandžić and Šmit, 2010), makes the text a form of aesthetic biographism, internal, sometimes covert, combining virtual and real traits, but in any case, the reader faces personality's life. Postmodernism witnesses "humiliation" of the fate by universal constructions, preventing life from personification in earthly and existential universal generalizations. A literary work is a part of the "fate" as life act. It implies systemic interaction between "life" and "text".

Literary community is in need of neomodernism, but not shaped in extravagant manifestos and extraordinary character of some literary "pose". Neomodernism (as a positive literary reality) could make a number of significant contributions: to do away with perception of literature as forever subjective game; to address the nature of personified aesthetic worlds; to elevate moral and didactic statuses of literary arts; to enhance and intensify connection between images and concepts of the past and the future.

Narration strategies, though popular in literature over the past decades, do not seem very attractive. It is far more important to read 
contemporary texts as messages of the 21st century man, to assess a piece of fiction as a diagnostic tool, not for a certain writer and his subjective world, but the created society as a whole. Interdisciplinary character of methodology, combining literature studies and sociology, aesthetics, psychology and even religious studies, requires comprehensive judgments, when novel represents personality phenomenon of contemporary era. Such books as Mimesis by Erich Auerbach (2003), The Poetics of Early Russian Literature by Dmitry Likhachev (1967), The Poetics of Early Byzantine Literature by Sergey Averintsev (1977), The Western Canon by Harold Bloom (1994) are particularly relevant for the research in question. Bearing uniqueness, these scientific projects start with comprehensive analysis of the model, literary recreated or manifested in national rhetoric tradition, and ends with the judgment of the key images of man, making this tradition genuine.

Both modern European (e.g. Demon Theory by Antoine Compagnon (2014)) and contemporary Russian literary criticism (e.g. The Theory of Literature. Problems and Results by Sergey Zenkin (2017)) acknowledge scientific crisis in studying different content and reception forms of the literary work. Anthropocentric view have become irrelevant due to lingua-centrism strengthening, fear of moral and philosophical judgments on literary reality, postmodern technologism which repulses from perceived "totalitarity" of aesthetic discourses. The current research under the context of combining "criticism" and "science", "human science" and "text studies" is aimed at enhancing effectiveness of the literary word, which should revive its interdisciplinary status and provide space for the dialogue between philosophers and psychologists, sociologists and culture experts. Images of man, created by contemporary writers, could depict not only the state of today fiction, but to reveal formation vectors of the idea of man in the nearest future, aspiring for relevance of idelogeme.

\section{Methodology}

Principles of material selection include the following. Concerned and at times aggressive presence of a writer in literary process - both through the number of works, frequency of publicist remarks, desire to take a niche in new Russian literature. Methodological ambivalence of authors, their uneasy attitude to the relations of utopia and anti-utopia (Malenica and Šmit, 2015; Givens, 2016; Gillespie, 2016), modern and postmodern (Chrząszcz, 2017), classical realism and new realism, literary centrism and didactic aspects of literary arts. Artistic quality of novels and stories, rightful claims on ideological, moral and philosophical completeness, activity of different reception forms. Concerned, easily defined attitude to the inheritance of Russian modernism encouraging not only aesthetic experiment, but also implying ideological vector of the plot that can be a sign of certain spiritual and moral position.

The following works of poetry refer to the indicated principles - Blue Blood (Buida, 2011), Thief, Spy and Murderer (Buida, 2013) and stories by Buida Poison and Honey (Buida, 2014), novels by Ulitskaya Daniel Stein, Translator (Ulitskaya, 2006), The Big Green Tent (Ulitskaya, 2011), Jacob's Ladder (Ulitskaya, 2015), novels In Syrah (Limonov, 2012b), The Old Man (Limonov, 2014) and artistic essay by Limonov Illuminations (Limonov, 2012a), novels by Pelevin The Sacred book of Werewolf (Pelevin, 2004), T (Pelevin, 2009), and Trilogy (Sorokin, 2006), Day of the Oprichnik (Sorokin, 2006), Tellurgia (Sorokin, 2013) by Sorokin.

These texts allow not only to solve the problem of man in certain artistic systems, but to provide the insight into the fictional worlds of the five prominent Russian writers. The main objective of this research is a comprehensive view of anthropological knowledge presented in artistic form (not separate analysis of every text as a kind of preliminary work). The main studying principle is focused academic reading of the selected literary works that recreate comprehensive image of man in the frames of poetics by Buida, Ulitskaya, Limonov, Sorokin, Pelevin.

Let us briefly outline their narrative strategies: creating an ambivalent figure of utopian and antiutopian consciousness (Sorokin, Pelevin) under the context of different epics of the new, utterly individualized type; aestheticization of the pivotal problems of human fate and outlining the problem of rhetoric way out of the crisis (Buida); creating unity of plot and language, in which words about the state (the world as whole), about totalitarian motives of its existence and words about personal (author's) inclusion in hierarchical system closely interrelate (Limonov, Ulitskaya).

\section{Results and Discussion}

Buida shows preference to the man who can be reasonably called "hero-intention": the issue of 


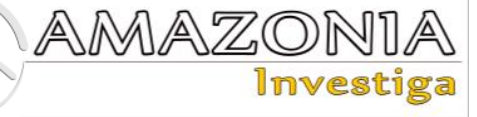

aim setting turns to be the most essential; the reader is invited to follow the life-long plot and fate, which is either complete or implements basic ideas for making preliminary conclusions and meaningful statements concerning the man, as it was the case with Thief, Spy and Murderer (Buida, 2013).

Intention integral to the hero and personality formation is coupled with ideological structure of the writing. Nevertheless, ideological sphere does not seem to be essential in Yu. Buida's fictional world. Idea (as a constant of thought and sense assimilated into the consciousness) falls under more powerful reality - style. Style is the core of personality, its dominating ideologeme, a way to define the character under existence seeking compromise.

"The protagonist cosmises existence and fights chaos - that is a brief formula of the events occurring in Blue Blood", Grimova (2013) writes, emphasizing anti-entropic trends of. Buida's fiction. That is the exact nature of modern, which is reflected in the fact that both poles (creative and moral, elitist and egocentric) are relevant. Sokhareva (2014) highlights this problem analyzing Poison and Honey.

Home is the only "live" character, willful and capricious, intolerant of any strangers. Main feature of his characters is cold, deadly domination, forgiven for everything... (...) Truth as a category evades from here... (Sokhareva, 2014)

Firstly, "man-intention". Secondly, style as a form of plan implementation. Poetics of state acquires specific meaning under interrelation of the above-mentioned poles. Life of main characters is abundant in events, deprived of external peace, filled with dramas and calamities, involves crime - not particular crime contexts, but spontaneous acts, drawing the man into reality which stipulates criminal liability. Despite dynamics the character retains spiritual self and unchanging attitudes. Following the plan is not transformation and replacement of ideological beliefs, but development over time of some stable modernist condition. This process is particularly representative in Blue Blood and Poison and Honey, and in Thief, Spy and Murderer too. The latter can be classified as an "educating novel" by form, while by content the protagonist moving through times and spaces, intensifying initial aesthetic attitude to reality. The intention (to "become a writer") is fully achieved in the end of the novel. However the style, which the narrator refers to the concept of "writer", has been on the forefront throughout narration.

Basic principles shaping neomodernist concept of person in Buida's works of fiction are as follows. The man is prone to illogical act, unconscious and impulsive moves, to the downfalls, thoroughly reconstituted by the author; ethic assessment of such situations is not crucial for the author. The character is willing to become the embodied intention, but is more likely (at least to the bystander - the reader) to signify permanent state. Stepping towards love or compassion, religion or politics, arts or active life building, the person is often faced with emptiness, absurdity, and meaningless world. Aesthetic self-realization, life-theatre (Bobileva and Prokhorova, 2016), transformation of personal existence into structurally perfect performance is a challenge for those seeking essence of artistic creation in the emptiness.

Resenting "dogmatic person" is the initial move (intellectual and aesthetic) in Ulitskaya's fiction. Systemic criticism of mind, free from selfcriticism, is clearly distinguished there. Communism or orthodoxy, fascism and common aggression are not acceptable for the characters. "Dogmatic man" is a frequently discussed object. It is repulsed by the plot and repeated remarks. They serve to point out the wrong ways of "dogmatists", imprisoned by their intolerance and criticism of other development paths of the inner world and social model.

Another meaningful point within the problem of the person concept - defense of a universal man, Daniel Stein being the brightest example. Ulitskaya recreates not theoretical, but practical person, addressing to people and concerned with "small matters". They are productive in understandable, commonplace kindness. To pursue these deeds Stein is ready to cooperate with fascists, communists, Jews, Christians of any confession, and Muslims. Israel is shown here not as a closed defensive state, but as the land enabling and necessitating ascent to the initial Christ - the Jew who produced universal teaching on interpersonal relations.

As Shishkova-Shipunova (2007) states, the protagonist of Ulitskaya's novel is a modernist in the field of "translating" classical Christianity into the "language" of "intellectuals", when common morality comes to the fore and surpasses, for instance, the Symbol of belief, which is undoubtedly altered by Stein. 
Through various languages Daniel has been trying to "build bridges" between all and all, to help all understand all. ... According to Lyudmila Ulitskaya, he is an interpreter (see the book title), mere interpreter. From eternal to common. From the God's language to human. But he is a righteous person. Orthopraxy (right deeds) for him is more significant than orthodoxy (right thoughts). And he encourages his flock to act according to their conscience, love, "as they want to be treated by others" (Christ taught the same). (Shishkova-Shipunova, 2007).

Rebel's (2007) position is less agreeable:

Ulitskaya described Daniel as irresistibly touching, attractive, while natural and convincing. This image deepens, materializes and exposes that ideal essence, one of the cores of European culture and Russian literature in particular. (Rebel, 2007).

As to this quotation, Stein is a traditionalist, common universalist in assessing human phenomena. But this is false. Avoiding special religious pathos, Ulitskaya depicts her character as "theurgic" and even "demiurgic", able to universalize religious experience for the sake of solving crucial cultural and political problems. Daniel Stein, despite of all the changes in his life, "always remained identical to himself, and the continuum of his personality has never been questioned" (Vojvodić, 2011).

The third concept of understanding human essence by the author is admissible ambivalence. The fourth motive, forming author's concept of man, is related to the concept of "new Christian". The fifth sign in novels by Ulitskaya is culturecentrism. Images of ordinary people are common, evoking author's sympathy or antipathy depending on their moral intentions. But central to the novel are characters with extensive cultural experience and intellectual background. Personalism is another symbol of neomodern concept of man, established by Ulitskaya. For the personality to open up to the full extent, several criteria should be met: not to assimilate with the official style in its various forms, to learn culture not as scholastic but live soul-related object; remember the value of thought and its distinctiveness from ruling ideologies, religions, public platforms; have desire to grow and develop, retaining flexible independent mind even in mundane contexts.

Everyone should pursuit their "own way", testing various proposals from the world and rejecting those implying inner and outer "totalitarianism".
A person should live in cultural space and develop oneself in accord with world experience that unites personality with democratic development path. A person should be ready for dramatic conflicts of national and global, state and personal, worldly and philosophical, in order to make the most of the strive for independence and responsibility instilled in every person. These are key concepts of the author's vision of man in Ulitskaya's novels.

The concept of man in Limonov's fiction primarily manifests itself in the author's personal attributes and life arrangement. He becomes the hero of his own text.

Limonov tried out many various genres, but appears to be the best in writing about himself. Journalism, memoirs, fiction elegantly flow into each other, creating a strange, but quite viable “centaur" (Belyakov, 2007)

Merge of infantilism and heroism, philosophy and political intentions is characteristic of two autobiographical novels: In $V$ Syrah (Limonov, 2012) and The Old Man (Limonov, 2014). Obviously both texts oppose aging and imminent death, and favour youth, carefully preserved by the author at his advanced age. He speculates at length about his girlfriends, fit body, lack of fatigue in political battles, perfect state of mind, producing new extravagant ideas. The following motive penetrates the novels: man is someone who will inevitably have to face domestic life, routine, and their own body, doomed to aging.

Limonov often turns to the image of Faust and Goethe's tragedy in the frames of automythologization, as it is the case with Illuminations (Limonov, 2012). It can be viewed as a "scientific novel", despite being essentially modernist. On the one hand, scientific discourse stands out, stemming from exegetical prose interpretations of the Holy Scriptures. On the other hand, the focus stays with fantasy concept, the author's "fantasy", expressed in scientificliterary language, as if specifically invented by Limonov, not in literary-fiction one.

Creators are unaware of love and kindness. The Universe lacks any form of morality, it is absolutely free from ethical imperatives. The man ("domestic animal") therefore, exists in the world without a scrap of mercy. Regarding Jesus (Limonov occasionally turns to his image) is not an independent figure. The Creators, regardless the species they master, are aware of murder and suicidal instincts that are inherent to the mind. To subdue those instincts endangering energy 


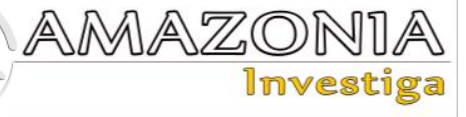

resources, the prophets of the Sky humility and submission appear, Jesus being one of them - the Creators' fellow, but not the people's Savior.

We witness the author's strive to glorify and mythologize his life, representing it as the fate of the most fascinating man of the time. However, automythologization is coupled with domestic contexts, defeating the hero's pathos. And the human himself is nothing more than a bio robot, energy food, a creature with originally not complicated functional task. However this "bio robot" starts to oppose the Creators as soon as he receives intelligence. The human is someone who can be overcome by life, mundane tasks, disgusting aging. Simultaneously he has to struggle, combining action with thought. Then it appears possible to approach the archetype of Faust and combat meanness of mundane life.

Literary works by Sorokin and Pelevin serve as grounded arguments to prove the hypothesis of the contemporary Russian neomodernism. Deconstructions and criticism of meta stories, corrective irony and thoroughly constructed intertext are characteristic of Sorokin's and Pelevin's fiction. Though integral to the novels anti-utopias, non-sarcastic religious moves, and implicit didactic figures are no less significant.

Classic modernism (e.g. Russian Silver Age prose and poetry) lies within the frames of gnostic paradigm. It implies not only religious component, but specially maintained intuition, minimizing material existence and daily human life. Lipovetsky integrates V. Sorokin into modernist rank:

Gnostic mythology is observed through Ice Trilogy: perceiving the world as evil, and body as the spirit's dungeon; and metaphor of the Light (brought by the Tunguska meteor) as the symbol of "alien" but genuine life; and the motive of original sacred name; and search of chosen "pneumatics" prone to Gnostics (Lipovetsky, 2000)

Pelevin apparently belongs here too, being the most illusionistic, deceitful "modernist" in the contemporary literature. Primochkina emphasizes Gnostics of the Pelevin's artistic search:

Pelevin too believes human life to be eternal and painful suffering. He considers God to have created this world "only as a mockery at the very idea that such world can exist". (Primochkina, 2010)
The pursuit of death is one of the most persistent desires in V. Sorokin's fiction. The protagonist dies at war, of drug overdose and chronic alcohol addiction, falls victim to the totalitarian state and his own vices resulting in incurable manias. "Sorokin's human" is prone to suicide and selfdestruction (as in Telluria) under the pretext of "communist", "Wahhabi", "monarchical", "nationalist", "knightly", "love and sentimental" rhetorics.

Sexuality is the focus of attention in Telluria (Sorokin, 2013). Telluria, as a form of humanity realization. Romantic homosexuals are writing lengthy letters to the west about their Moskovia adventures; "non-wicked" abusers yearning for pleasure; manic maids voyeuring hotel residents making love; passion-obsessed women exploiting male genitals, which function independently. Sexuality in Sorokin's view is essential part of humanity, uniting violence and love, animalistic nature and strive for superhuman trances.

Dehumanization of Alexander Snigirev (Bro) and his fellows is exquisitely and skillfully described in the Ice Trilogy. They came to awaken and realize their non-human nature and their true purpose: to demolish the Earth as a big mistake of ethereal Rays, reflected in water and turning them into bodies doomed to die. A significant scope of the text contains radical abuse of the human being and human existence, not just surmounting. Gnostic essence (concordant to modern) is coupled with the totalitarian: the nearer the space, ice, emptiness, the farther the human is. Thus, prison violence towards him is not accidental, but spiritual and social project.

Particularly interesting is Sorokin's narration on the part of brothers of Light, without even concealing their inhuman essence. But humanity is depicted with great misanthropy (even Swift's guingms are more tolerant to the yahoo: they disdain them, yet allow them to eat rotten food, copulate, reproduce, exist), and Light brothers' hunger for heart is so vigorously described, that the reader voluntarily get dragged into the brotherhood chains. Swapping moral poles is a much more intricate task than to juggle styles and discourses, and Sorokin meets this challenge perfectly. (Latynina, 2006).

The critic reasonably emphasized the core action: Sorokin is primarily concerned with spiritual impulses, "moral" poles, not mere play with styles and discourses. 
Day of the Oprichnik (Sorokin, 2006) belongs between Trilogy and Telluria both in time and content. This small futurist novel contains negation of "commonplace goodness", and passion for historiosophic discourse. At one extreme, much is spoken about traditional Russian doctrines, their implementation in Ivan the Terrible's ruling. At the other extreme, Komyaga, Batya and other oprichniks behave in a way that witnesses to the instinct as the crucial point, implemented in various rhetorical figures. It appears impossible to conceal the main thing: man is a cruel being, onthologically prone to violence.

Sorokin's concept of man comprises a variety of elements: Gnostic arrogance, betting on instinct, craving for cruelty, interest for pathetic rhetorics and superficial righteousness, desire to transform one's own consciousness with substances, and to create ideal state in accord with medieval methods. There is pursuit of the stars and dreams of emptiness. And what misses is authentic love of humans, forever central to the classical fiction discourse.

In his every text Pelevin speaks about empty humans, vanished (as moral personality) in mass culture, which deprives of individuality. This emptiness is dehumanizing, with money, commercial images and consuming world forcing the man to follow the ways of creators, who submit minds to mental, verbal and material garbage. Yet there is another Void, neomodern, synonymous to spiritual movement rather than absence of the latter. This Void (integral to most of Pelevin's texts) gives up on all bright, prop images of untrue existence, and on entering it the human seizes to be the mind "smeared" with endless hectic of modern times.

Pelevin is rather a didactic writer than entertaining and mass one. Analyzing his novel "Empire V" (Pelevin, 2006), Galina says:

Pelevin is the one to have constructed noncontroversial conception. Non-controversial means simplified on the one hand (only simplicity works), and, on the other hand, closed for development and interpretation, i.e. dead in fact. Details (God is in the details) are out of place here - such simplicity is permissible only when dealing with general notions, schemes. Consequently, humanity is out of place too. Probably it was due to this that a number of critics regarded Pelevin's novel a fail. However, I insist that Pelevin was writing not a novel, but a belletricized treatise. The worst part of it is that he managed to write it. (Galina, 2013)
Dyakova agrees with author's general "cynicism" but considers his "moral story" possible and necessary:

Paradoxically, all that immense cynicism towards people, their culture, life, and work perfectly amplifies final "sententions", the "moral", that would be taken for cheap commonplace truths, in case they are out of context. However within the context they seem hard-won and imminent. (Dyakova, 2007)

Whether the personality remains or disappears in course of this motion, as according to Buddhist belief, disappears any individuality? Whatever the answer, the issue of new personality turns to be crucial for Pelevin, regarding the two forms of emptiness (negative and positive), and the character's path towards enlightment (at least his exemption from "glamour" and "discourse"). The issue gains more significance when it becomes clear that it is neither a classical "European personality", positioning himself or herself in the context of self-determining, developing egocentrism, nor a "Christian personality" employing humbleness and sacrifice as the key to all human problems.

That is the case with the novel " $T$ ", the main pathos of which is that a person should seize to be the "hero" of "alien", troubled plots, and to achieve "author's" status, being the only arbiter of his or her personal reality. It is time to turn from the created into creating, from "reader", to "writer", able to take responsibility for the unfolding text of "life".

Pelevin seeks to solve the problem of human through superhuman: werewolves, vampires attract the author with their rough, cynical views, rejection of mundane existence, and the power they possess. In Pelevin's view life is suffering, but this suffering is specific, depicted by the author with sarcasm rather than compassion. To state it more generally: a human in its standard variant is the creature who is worth contempt. A human perishes under the burden of his or her own thoughts, words, actions, all extraneous to the clear mind.

The four underlying points could characterize "Pelevin's man". Firstly, this is mind, attacked by internal and external forces, images and concepts of contemporary culture, striving to deprive personalities of their power within the consumption field. Secondly, it is tough, cynical self, able to assess unpleasant human world and make a step towards "superhumanity", embodied in vampires, werewolves, "Orient" masters, etc. 


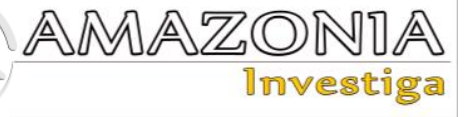

Thirdly, the person dissatisfied with the secondary role is to give up being the hero of the "imposed" story and achieve "author's" status, choosing his own way. Fourthly, an encounter with the "Orient" is required, and it will explain that happiness and unhappiness are in the man's hands, and his genuine nature is inherent to the Emptiness, not vanity.

We suggest two new research stages as a result of collaboration with Zhitenev's works (as well as with the participants of the discussion on his book), Zatonsky's, authors of numerous articles on contemporary prose, who address methodological complexity of the contemporary literature in publicist traditions. The first implies focus of hermeneutic efforts on the issue of personality, centering plot and speech intentions of the literary word. The second one implies transition from methodological ambivalence to relative methodological concreteness." Neomodernism" is promising in terms of poetics (structural and informative aspects of contemporary novels) and pragmatics (intensifying relevant perceptions of literary art). We will highlight only one of the research perspectives. Literature (Russia, European, and American) witnesses increasing trends of linguistic (literary text signals about language condition) and sociological (text is indicative of society state) interpretation of the literary word. Reminding that literary work carries significant potential for generating anthropocentric ideas, we are hereby inviting the researchers of contemporary aesthetic discourses to interpret literary texts as moral, not merely narrative intrigues. They are indeed essential to establish contacts between art and society, philological hermeneutics and forecasting humanitarian processes. The concept of man within neomodernsm poetics is a significant way to study contemporary fiction as informative story messages about moral state of the world, its psychological, religious and philosophical attitudes.

The focus is artistic construction of "totalitarian/antitotalitarian", "dogmatic" personality, actively interacting with the images of Faust, Hamlet, "Soviet" and "Oriental" man, solving existence problems in this specific world, characterized by the atmosphere of meaningful emptiness. The obtained results could be helpful for scholars, engaged in the following humanitarian fields. Firstly, literary scholars, analyzing literary text as ideological and even didactic complex. Secondly, for psychologists, philosophers, and probably religious scholars who observe changes and symptoms of contemporary culture, various inversions of canonic stories, images and concepts, and are ready to make diagnostic conclusions, by which literary sources serve adaptation of general humanitarian (not solely philological) statements. Thirdly, for the theorists of literature and culture, considering growing postmodernism crisis and necessity to find new hermeneutic codes for defining key intentions of the early $21 \mathrm{st}$ century cultural progress. Theoretic and practical "neomodernism" concept seems especially perspective in terms of literary anthropocentrism.

\section{Conclusions}

"Antitotalitarial man" is one of the dominants in resolving the personality problem in contemporary Russian literature. Two points deserve special attention here. Firstly, totalitarianism is combined with the state, social and historic sphere. Secondly (no less important), totalitarian principles are traced in the beginning of the world and human existence. Some authors (as Ulitskaya) demonstrate greater interest to social totalitarianism, others (as Pelevin) - to metaphysical totalitarianism. Whereas there is merge of religious and philosophical motives with social and historical ones in a single antitotalitarian complex, in neo-modernist personified effort.

Modern Russian prose reconstructs the person type, immersed in special ambivalence profoundly developed by the author. In this case totalitarian and anti-totalitarian synthesize, so the author has no answer to the question about author's hero and his main intentions. "Yes" and "no" to the "totalitarian man" (in unity of characterologique, philosophical, and sometimes political attitudes) sounds equally intensive in the artistic worlds of Limonov, Sorokin, Buida.

Hamlet is the center of archetypical intentions, affecting the images of man in contemporary Russian prose. It is due to the Shakespearian character, and intuition he symbolizes. The intuition relates to crisis interaction with the "empty" world under increasing Gnostic claims to human existence and invariably complicated relations with such immense structures as society or state. Faust archetype is relevant under growing egocentric, willful intentions of the subjective character, ready to uneasy forms of agreements with different powers in order to bring to life some plan. Faust is obvious with Limonov's works, but Buida, Sorokin employ his image as well. The "Soviet man" with his complexes, ups and downs, heroism and betrayal 
fascinates all of the five authors, mentioned in this literary research.

Having investigated the image of man in contemporary Russian prose in the context of the 21st century neo-modernism, enabled us to point out its The underlying features:

- author's urge for subjectifying and individualizing artistic discourse;

- $\quad$ aspiration to personify the poetics, resulting in exclusively author's plot and protagonist;

- fictional metaphysics and fictional historiosophy are of utmost importance to the narration, they are tackled in noncanonic contexts as all significant challenges;

- publicist and even political tendencies in text structure, however with the sense of internal theurginess, its super-social, timeless value;

- ambivalent relations between utopian and anti-utopian discourses, prompt transformation of ironic narratives into pathetic ones;

- interest to literary, religious and philosophical archetypes, helpful in intensifying ideological sphere of the novel, and reconstructing its neomythologism;

- focused attention to emptiness, which is not only multifaceted, but forms the context of existence, where the person is to cope with existence challenges.

And here goes the final remark. Firstly, as to the theoretic and methodological aspect, we assess neo-modernism as the established poetics of contemporary prose. Secondly, as to the pragmatics, the term "neo-modernism" should be used in the pursuit of enhancing the status of contemporary literature, one might say, its justification.

\section{Bibliographic references}

Auerbach, E. (2003). Mimesis: The Representation of Reality in Western Literature. Fiftieth Anniversary Edition. Princeton: Princeton University Press.

Averintsev, S. (1977). The Poetics of Early Byzantine Literature. Moscow: Publishing house Science (in Russian).

Belyakov, S. (2007). Don Quixote from Haifa. Novy Mir, 5. Available at http://magazines.russ.ru/novyi_mi/2007/5/be13.ht $\mathrm{ml}$ (in Russian)

Bobileva, A.L. and Prokhorova, T. (2016). The interaction between the theatrical and fairytale discourses of Yuri Buida's novel "Blue blood". Journal of Language and Literature, 7(3), 206-210.
Bloom, H. (1994). The Western Canon: The Books and School of the Ages. New York: Harcourt Brace. Buida, Y.V. (2011). Blue Blood. Moscow: Eksmo. http://loveread.ec/view_global.php?id=34202 (in Russian).

Buida, Y.V. (2013). Thief, Spy and Murderer. Moscow: Eksmo. http://loveread.ec/view_global.php?id=17865 (in Russian).

Buida, Y.V. (2014). Poison and honey. Moscow: Eksmo.

http://loveread.ec/view_global.php?id=36291

(in Russian).

Chrząszcz, M. (2017). An object in a human development to maturity. The Big green tent by Ludmila Ulitskaya. Studia Literaria Universitatis Iagellonicae Cracoviensis, 12 (4), 245-253, http://dx.doi.org/10.4467/20843933ST.17.020.778 5

Compagnon, A. (2014). The Demon of Theory. Literature and common sense. Paris: Points.

Doraiswamy, R. (2007). Politics and literature in Russia: Recent trends. International Studies, 44 (4), 305-315,

http://dx.doi.org/10.1177/002088170704400402

Dyakova, K. (2007). Experiments. "Empire V" reader's margin notes. Novy Mir, 9. Available at https://magazines.gorky.media/novyi_mi/2007/9/c hitatelskie-zametki-na-polyah-empire-v.html (in Russian)

Galina, M. (2013). Undead choosing us, or once more about 'Vampire Novels' by Victor Pelevin. Novy Mir, 8. Available at http://magazines.russ.ru/novyi_mi/2013/8/20m.ht $\mathrm{ml}$ (in Russian)

Gillespie, D. (2016). Vladimir Sorokin and the return of history. In Tabachnikova, O. (Ed.), Facets of Russian Irrationalism between Art and Life: Mystery inside Enigma, 61, 519-530. Leiden: Brill, http://dx.doi.org/10.1163/9789004311121_025

Givens, J. (2016). New directions in Russian literature. Russian Studies in Literature, 52(1), 1-6, http://dx.doi.org/10.1080/10611975.2016.1189294 Grimova, O. (2013). Narrative intrigue in Yury Buida's 'Blue Blood'. Narratorium, 1-2. Available at

http://narratorium.rggu.ru/article.html?id=2631078 (in Russian)

Kovtun, N. and Razumovskaya, V. (2017). Nabokov's code in the early works by L. Ulitskaya: Literary criticism and translation aspects. In 4th International SGEM Conference Proceedings, 6 (2), 555-562. Available at https://sgemsocial.org/ssgemlib/spip.php?article51 30\&lang=en

Latynina, A.N. (2006). Super-man or inhuman? Novy Mir, 4. Available at http://magazines.russ.ru/novyi_mi/2006/4/lat9.htm 1 (in Russian)

Likhachev, D.S. (1967). The Poetics of Old Russian Literature. Leningrad: Nauka (in Russian). 


\section{$\mathbb{A} M \mathbb{A} Z \mathbb{Z} O N D \mathbb{A}$}

Limonov, E.V. (2014). The Old Man. Moscow: Limbuss Press. http://loveread.ec/view_global.php?id=40747 (in Russian).

Limonov, E.V. (2012a). Illuminations. Moscow: Ad Marginem Press. http://loveread.ec/view_global.php?id=54543 (in Russian).

Limonov, E.V. (2012b). In Syrah. Moscow: K. Tublin Publishing House. http://loveread.ec/view_global.php?id=36620 (in Russian).

Lipovetsky, M. (2013). Sorokin-trop: Carnavalisation. NLO, 120. Available at http://magazines.russ.ru/nlo/2013/120/li11.html (in Russian)

Lipovetsky, M. (2000). Literature on the margins: Russian fiction in the Nineties. Studies in 20th Century Literature, 24(1), https://doi.org/10.4148/2334-4415.1478

Malenica, I. and Šmit, Z.M. (2015). Anti-utopian and Deconstructive Vision: Vladimir Sorokin, Blue Lard. Croatica et Slavica Iadertina, 11 (1), 193-202. Available at https://bib.irb.hr/datoteka/809078.Malenica_i_Mat ek_Smit_V._Sorokin_Plavo_salo.pdf

Pandžić, M. and Šmit, Z.M. (2010). Lyudmila Ulitskaya, 'The funeral party': The remnants of Soviet identity. In Stefanskij, E. [Ed.], International collection of scientific works on cultural linguistics: European mentality Through the Prism of Language, 126-133. Samara, Russia: Samarskaja gumanitarnaja akademija. https://www.bib.irb.hr/545528

Pelevin, V. (2006). Empire V. Moscow: Eksmo. http://loveread.me/view_global.php?id=2936 (in Russian)

Pelevin, V. (2004). The Sacred Book of the Werewolf. Moscow: Eksmo. http://loveread.me/view_global.php?id=2938 (in Russian)

Pelevin, V. (2009). T: novel. Moscow: Eksmo. http://loveread.me/view_global.php?id=2935 (in Russian)

Primochkina, N.N. (2010). On the classics background (review of the book: V. T. Pelevin, Roman. Moscow, 2009). NLO, 105. Available at http://magazines.russ.ru/nlo/2010/105/pr33.html (in Russian)

Rebel, G. (2007). Lyudmila Ulitskaya: Evish Issue? Friendship of Peoples, 7. Available at http://magazines.russ.ru/druzhba/2007/7/re14.html (in Russian)

Shishkova-Shipunova, S. (2007). Daniel Stein's code, or a good man from Haifa. Znamya, 9.
Available

at http://magazines.russ.ru/znamia/2007/9/sh13.html (in Russian)

Sokhareva, T. (2014). Author Drank Honey, Gazeta.Ru. Available at http://www.gazeta.ru/culture/2014/02/05/a_58835 97.shtml (in Russian)

Sorokin, V. (2006). Day of the Oprichnik. Moscow: Zakharov Books. http://loveread.ec/view_global.php?id=49832 (in Russian)

Sorokin, V. (2013). Telluria. Moscow: Corpus (AST).

http://loveread.ec/view_global.php?id=23220

(in Russian)

Sorokin, V. (2009). Trilogy, Moscow: Corpus (AST).

http://loveread.ec/view_global.php?id=37748 (in Russian)

Tatarinov, A. (2015). Ways of Contemporary Russian Prose. Moscow: Flinta: Nauka. https://www.litres.ru/a-v-tatarinov/puti-noveysheyrusskoy-prozy-uchebnoe-posobie/ (in Russian).

Ulitskaya, L. (2006). Daniel Stein, Interpreter. Moscow:

Eksmo. http://loveread.ec/view_global.php?id=3366

(in Russian).

Ulitskaya, L. (2015). Jacob's Ladder. Moscow: AST.

http://loveread.ec/view_global.php?id=50073

(in Russian).

Ulitskaya, L. (2011). The Big Green Tent. Moscow: Eksmo.

http://loveread.ec/view_global.php?id=3367

(in Russian).

Vojvodić, J. (2011). Daniel Steinus Transfers (international peer-review). Russian Literature, 69(1) 141-155,

http://dx.doi.org/10.1016/j.ruslit.2011.02.012

Zatonsky, D. (2000). Modernism and Postmodernism: Thoughts about Eternal Circulation of Fine and Non-fine arts. Kharkov, Ukraine: Folio. http://elcat.pnpu.edu.ua/docs/zatonskyy.pdf (in Russian)

Zhitenev, A. (2012). Neo-modernism Poetics. Saint-Petersburg: Inapress. https://www.phil.vsu.ru/science/pdf/zhitenev.pdf (in Russian)

Zenkin, S. (2017). The Theory of Literature. Problems and Results. Moscow: Publishing House "New Literary Review".https://www.nlobooks.ru/books/nauchnay a_biblioteka/17489/ 